\title{
PHLOEM ANATOMY OF THE CARBONIFEROUS PTERIDOSPERM MEDULLOSA AND EVOLUTIONARY TRENDS IN GYMNOSPERM PHLOEM
}

\author{
EDITH L. SMOOT
}

Department of Botany, Ohio State University, Columbus, Ohio 43210

\begin{abstract}
Secondary phloem anatomy is detailed for four species of Medullosa from various coal ball localities in North America, ranging from Lower-Middle to Upper Pennsylvanian. The zone of secondary phloem can be up to $3.7 \mathrm{~mm}$ wide and consists of alternating, tangential bands of sieve cells, phloem fibers, and axial parenchyma separated by parenchymatous rays. Fibers are up to $4.2 \mathrm{~mm}$ long, thick walled, and in bands up to five cells wide radially and two to three cells tangentially. Phloem parenchyma cells are generally much smaller in diameter than either the sieve elements or the fibers and occur in bands as wide as 12 cell layers. Sieve cells are up to $4.2 \mathrm{~mm}$ long, with circular-oval sieve areas on the radial walls. The sieve areas are relatively uncrowded and contain a number of dark spots interpreted as callose deposits. Some deposits completely cover individual sieve pores, while others appear to line the sieve pores. Phloem anatomy in Medullosa is compared with that in other genera of Paleozoic seed fems and extant gymnosperms.
\end{abstract}

\section{Introduction}

The late Paleozoic seed fern Medullosa is well known from coal ball localities in North America and Europe. The taxon was instituted by соттA (1832) for structurally preserved stems of Permian age and is characterized by a large number of vascular segments in cross section ("steles" of earlier workers). Medullosa was originally thought to possess a polystelic vascular system, but BASINGER et al. (1974) studied leaf trace production in these stems and suggested that the cauline vasculature was fundamentally monostelic, as in other Carboniferous seed ferns.

Although phloem anatomy has not been used as extensively in systematic studies as wood anatomy, a few studies have applied anatomical (CHANG 1954; ZAHUR 1959) and $\bullet$ ultrastructural (BEHNKE $1972,1974,1981)$ characteristics of phloem to systematic problems in angiosperms and gymnosperms. To date, this approach has not been used with fossil plants, probably because of the small number of fossil taxa with well-known phloem structure. The Carboniferous pteridosperms represent an excellent group in which to examine the phylogenetic and taxonomic importance of phloem anatomy. Phloem in several genera of seed ferns has already been examined and is sufficiently preserved to enable one to discern critical anatomical details. The secondary phloem of Heterangium (HALL 1952) and Callistophyton (BERTRAND and RENAULT 1886; RUSSIN 1981) has been described in detail from Upper Carboniferous specimens. Phloem structure in Calamopitys, a stratigraphically older member of the seed ferns (Lower Visean), has been described from European material (GALTIER and H£BANT 1973).

Current address: Department of Biology, Hope College, Holland, Michigan 49423.

Manuscript received October 1983; revised manuscript received January 1984.
In general, both the vegetative and reproductive anatomy of the Pennsylvanian seed ferns is well known, largely from coal balls. Most important, the quality of preservation of the material in the present study is sufficiently good to facilitate comparison with other Carboniferous pteridosperms and with extant gymnosperms.

\section{Material and methods}

Stems of Medullosa were found in coal balls collected at various localities in North America, including Berryville, Illinois (Upper Pennsylvanian, Calhoun Coal, Mattoon Formation, McLeansboro Group, Sumner 15' Quad., Sec. 7, T2N R13W, Lawrence Co., 111.), Lewis Creek, Kentucky (Lower-Middle Pennsylvanian, Hamlin Coal, Breathitt Formation, Cutchin 7.5' Quad., Leslie Co., Ky.), Sahara, Illinois (Middle Pennsylvanian, Herrin no. 6 Coal, Carbondale Formation, Kewanee Group, Harrisburg 15' Quad., Sec. 30, T9S R4E, Williamson Co., 111.), and Steubenville, Ohio (Upper Pennsylvanian, Duquesne Coal, Duquesne Formation, Wayne Twp., Sec. 6, NE $1 / 4, \mathrm{SE} / 4, \mathrm{SE}$ Jefferson Co., Ohio).

Material was prepared for light microscopy by the cellulose acetate peel technique (JOY et al. 1956; STEWART and TAYLOR 1965). To increase the contrast of the fiber cell walls, some of the peels were stained in malachite green (BARTHOLOMEW et al. 1970). Measurements were made either with an ocular micrometer or on a Zeiss Videoplan image analyzer. However, most sieve pores were either too indistinct to measure accurately by transmitted light or were obscured with callose. In these cases, an estimate of pore size was obtained from scanning electron micrographs. Small pieces of the axes were mounted on stubs and prepared by etching for 5-10 min in dilute $\mathrm{HC} 1$ ( $2 \%$ of stock), followed by $10 \mathrm{~min}$ in saturated EDTA (ethylene-diaminetetraacetic acid) (Sмоот 1979). The rock was dried, 
coated with gold, and viewed with a Hitachi S-500 instrument.

Slides, peels, stubs, and slabs of coal ball nos. $66,831,861,1695,1696$, and 8342 are deposited in the Paleobotanical Collections, Department of Botany, Ohio State University, Columbus, under acquisition nos. 10,258-10,453, and 13,03513,175 . Slides, peels, and slabs from coal ball no. 137 are deposited in the Paleobotanical Collection, Department of Biology, Western Illinois University, Macomb; those from coal ball nos. 272, 434, and 1379 are deposited in the Paleobotanical Herbarium, Department of Botany, Ohio University, Athens, under acquisition nos. 6471-6546; specimens of Medullosa endocentrica are in the Paleobotanical Collection, Department of Biology, University of Kansas, Lawrence.

\section{Observations}

GENERAL ANATOMY

Phloem is present in stems of Medullosa anglica Scott (from Lewis Creek, Ky., coal balls nos. 1695 and 1696), M. endocentrica Baxter (Berryville, 111.), M. noei Steidtmann (Berryville and Sahara, 111, coal ball nos. 66, 137, 272, 831, 861, 8342), and Medullosa sp. (Steubenville, Ohio, coal ball nos. 434 and 1379). Medullosa endocentrica represents the type material of this species. The stems of M. noei are the largest, up to $10 \mathrm{~cm}$ in diameter; those of $M$. anglica average $4 \times 14 \mathrm{~cm}$ in diameter; those of $\boldsymbol{M}$. endocentrica are ca. $1.0 \mathrm{~cm}$ in diameter; and those of Medullosa sp. are the smallest, ca. $1.8 \mathrm{x}$ $0.7 \mathrm{~cm}$ in diameter. The axes contain a variable number of vascular segments, each with a central region of primary xylem and parenchyma, surrounded by a broad zone of secondary xylem. The wood is manoxylic, with rays present about every two to four rows of tracheids (fig. 1). Secondary tracheids have scalariform pitting, and their crosssectional diameter decreases gradually from the firstformed cells next to the primary xylem (ca. $260 \mathrm{x}$ $210 \mathrm{jjim})$ to the most recently formed ones near the cambium (200 x $177 \mid \mathrm{xm})$. The vascular segments are embedded in a parenchymatous ground tissue that contains scattered secretory cells (fig. 1).

In some specimens, thin-walled cells of a vascular cambium are present (fig. 2). This zone varies from one to three cells thick but is most often two cells wide. Cell diameter decreases rapidly from the large, presumably mature tracheids on one side to the first recognizable phloem fibers and sieve elements (ca. $65 \mathrm{lxm}$ in diameter) on the other (figs. $1,2)$.

\section{PHLOEM ANATOMY}

GENERAL.-Phloem anatomy in all species examined is similar. Preservation of the phloem varies but is generally more complete on the inner face of each vascular segment. Secondary phloem surrounds the individual vascular segments and consists of alternating, tangential bands of fibers, sieve elements, and parenchyma, separated by phloem rays (figs. $6,10,15)$. These bands are distinctive even at lower magnifications (fig. 4), and their pattern can be followed from the vascular cambium to the periphery of the secondary tissue, a distance of up to 45 cell layers (fig. 5).

The width of the zone of secondary phloem is variable and does not appear to be correlated with the size of the particular vascular segment or with the species involved. In addition, there seems to be no relationship between the number of xylem and phloem cells present within a single radial row. It is difficult to quantify this aspect of secondary development in Medullosa since only those specimens in which the xylem and phloem are preserved in their entirety can be considered.

Development of secondary phloem is compared with xylem within the same radial row in table 1 . All of the values are taken from a single stem of M. noei and show no clear relationship to one another but are affected by such features as trace departure and differential growth rates. For example, the radial rows with 46 and 50 phloem cells (18 and 16 xylem cells, respectively) were in a region of the stem that had recently produced a leaf trace, and the band of vascular tissue was considerably narrower than in other regions of the same section. The row with 66 phloem and 58 xylem cells included an area adjacent to the vascular cambium in which a number of narrow diameter derivative cells were apparently produced within a relatively short distance (fig. 3). On the other hand, the rows with 47 and 48 phloem cells (34 and 48 xylem cells, respectively) appeared normal in all respects.

AXIAL PARENCHYMa.- The phloem parenchyma consists of tangential rows of small-diameter cells bordering a band of fibers on the inside and sieve elements on the outside (figs. 6, 10). Each row of parenchyma extends from one ray to the next and may include up to 12 cells tangentially and one to two (occasionally three) cells radially (fig. 15).

$$
\text { TAB L E L }
$$

DEVELOPMENT OF PHLOEM AND XYLEM WITHIN THE SAME RADIAL ROW IN STEMS OF MEDULLOSA NOEI

\begin{tabular}{|c|c|c|c|}
\hline \multicolumn{2}{|c|}{ PHLOEM } & \multicolumn{2}{|c|}{ XYLEM } \\
\hline No. cells & $\begin{array}{l}\text { Width } \\
\text { of zone }\end{array}$ & No. cells & $\begin{array}{l}\text { Width } \\
\text { of zone }\end{array}$ \\
\hline 46 & $185 \mathrm{~mm}$ & 18 & $1.70 \mathrm{~mm}$ \\
\hline 47. & $255 \mathrm{~mm}$ & 34 & $7.50 \mathrm{~mm}$ \\
\hline 48 & $275 \mathrm{~mm}$ & 48 & $10.35 \mathrm{~mm}$ \\
\hline 50 & $2.10 \mathrm{~mm}$ & 16 & $1.75 \mathrm{~mm}$ \\
\hline 66. & $370 \mathrm{~mm}$ & 58 & $8.75 \mathrm{~mm}$ \\
\hline
\end{tabular}

${ }^{\text {a }} 831$ A, others $=831$ B, bot. 
FIGS. 1-5.-Phloem of Medullosa noei in cross section. Fig. 1, Section through part of a vascular segment, with secondary xylem, secondary phloem, and cortex containing large secretory canals (arrows). Note tissue continuity from xylem to cortex; 831 B bot, no. 2; X13. Fig. 2, Detail of vascular cambium; 831 A!, no. 4; X130. Fig. 3, Section through region of proliferated cambial cells, illustrating presumed "wound" response, i.e., production of a large number of smaller-diameter derivatives; 831 B, bot, no. 18; $x 42$. Fig. 4, Secondary phloem with repeating tangential bands of phloem cells. Note conspicuous rows of phloem fibers, which appear as slightly darker cells; 831 B, bot, no. 6; x36. Fig. 5, Specimen containing largest phloem zone $(4.0-4.5$ $\mathrm{mm}$ wide) with cells intact from vascular cambium out to peripheral phloem fibers; 831, A, no. 4; $x$ 14. $C=$ cortex, $F=$ phloem fibers, $P=$ secondary phloem, $V=$ vascular cambium, $X=$ secondary xylem. 

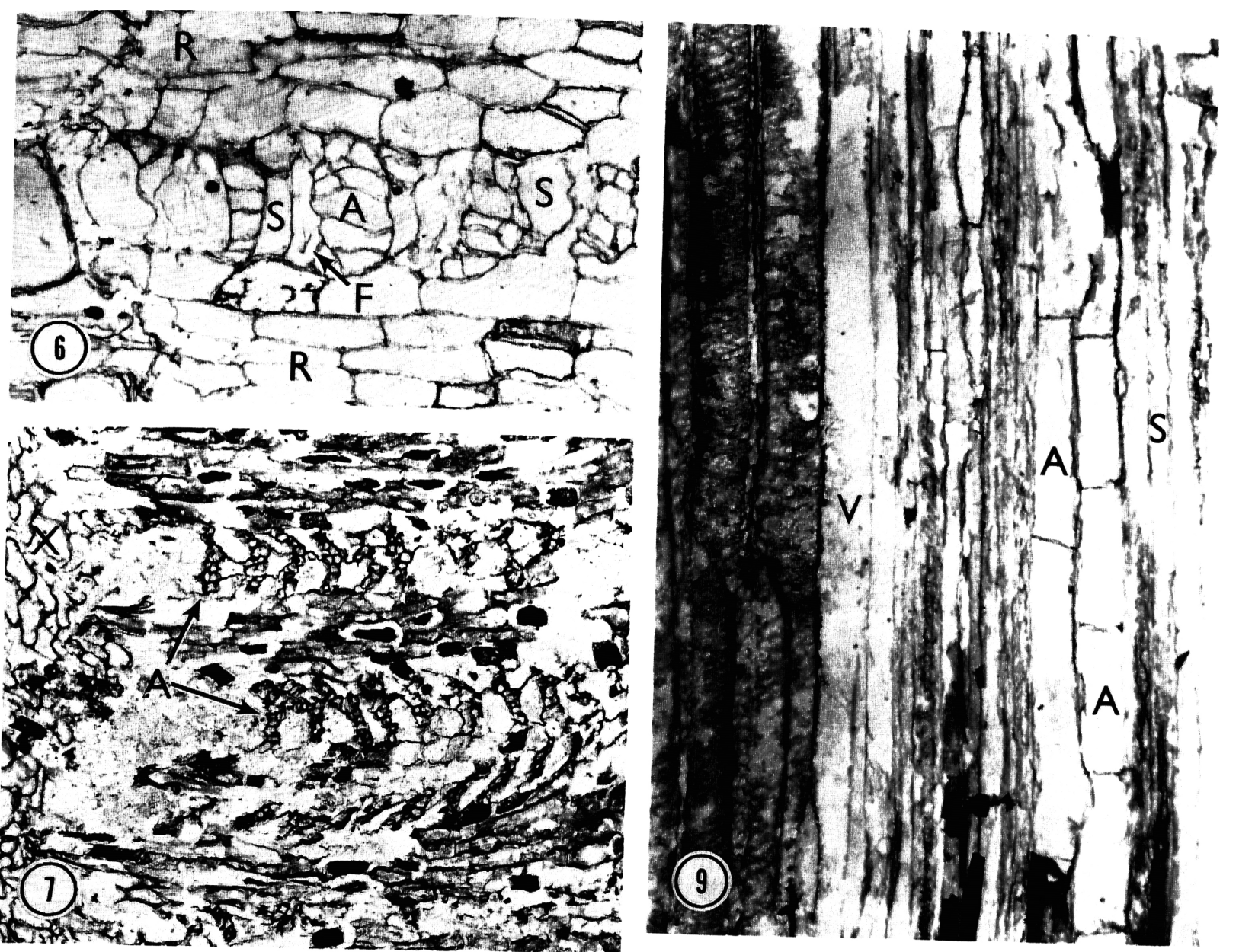

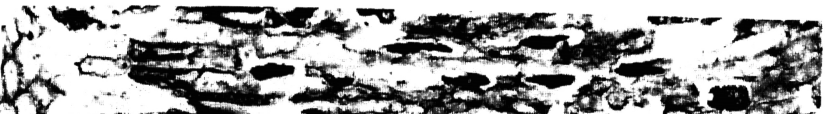

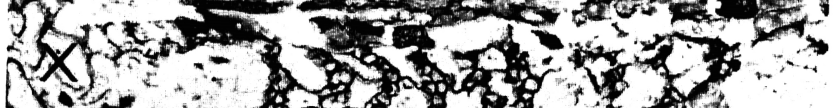

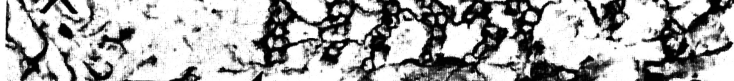

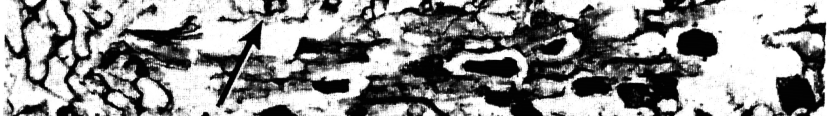

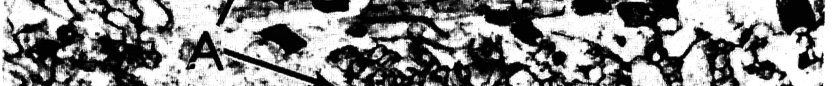

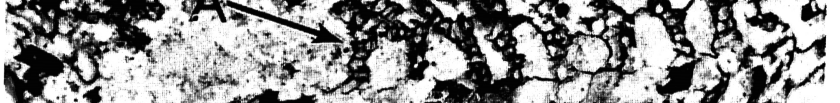

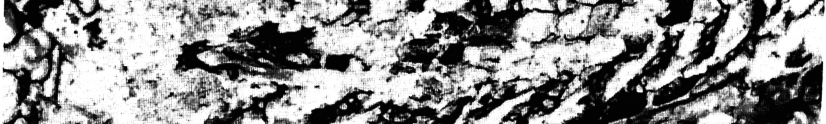

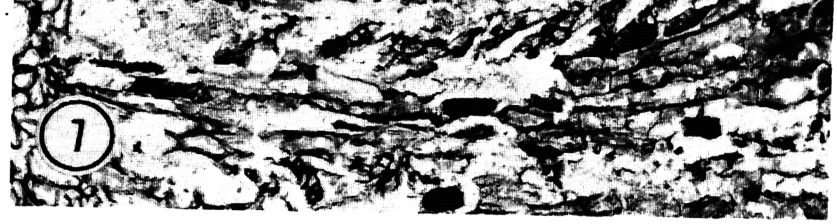

Wyin

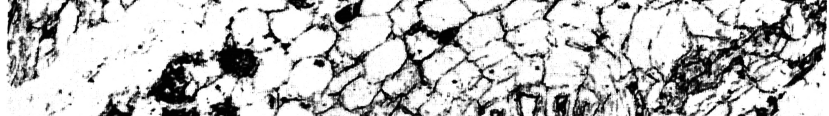

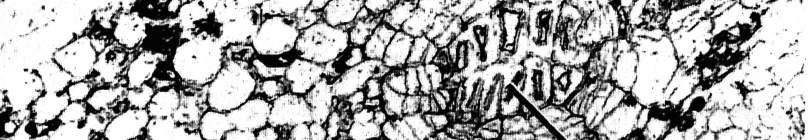

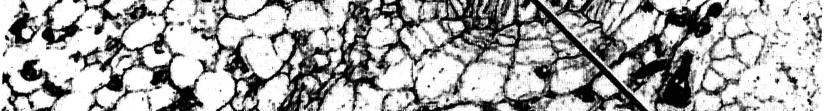

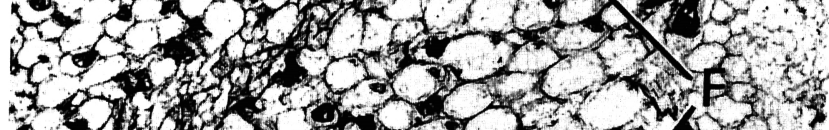

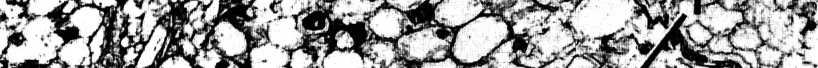

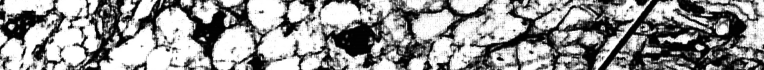
(5)

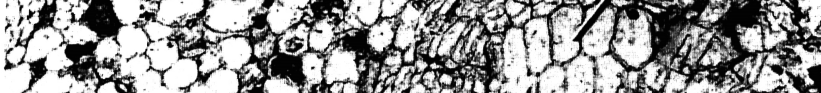

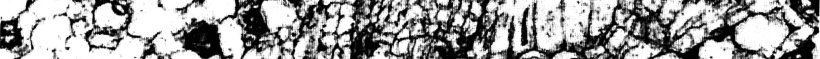
3.140,

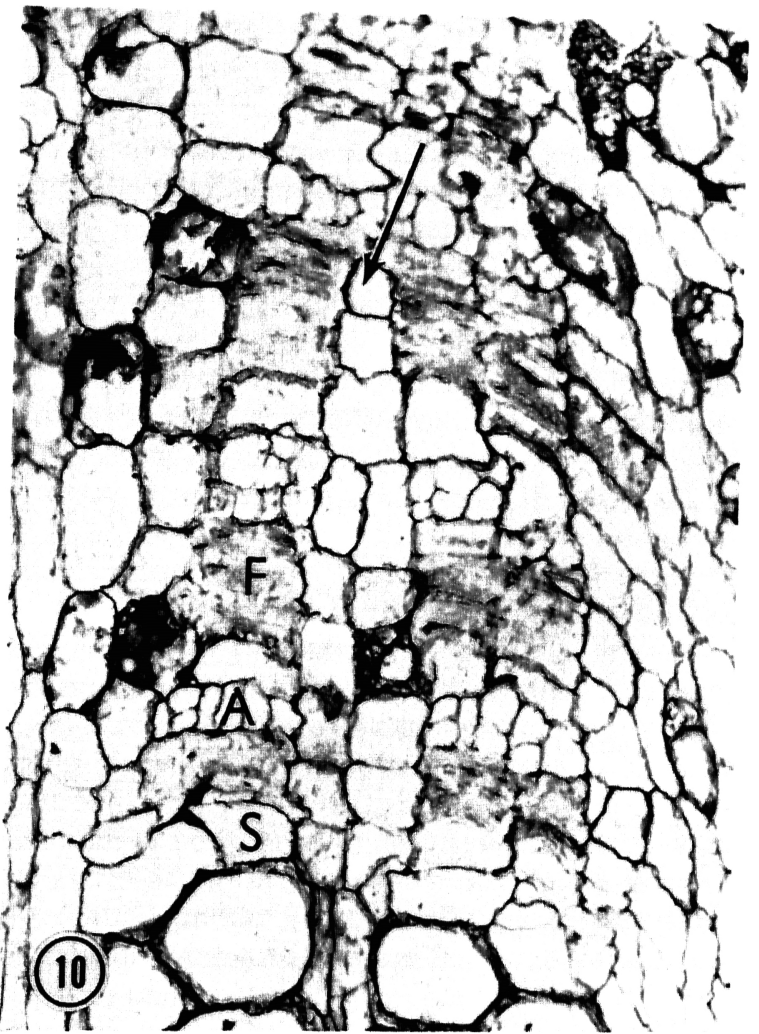

FIGS. 6-10.-Figs. 6, 8-10, Phloem of Medullosa noei; fig. 7, phloem of Medullosa sp. Fig. 6, Cross section of secondary phloem close to cambium, with rays above and below, phloem parenchyma, sieve cells, and fibers center. Unstained peel preparation-compare with fig. 15; $831 \mathrm{Bj}$ bot, no. 8; xllO. Fig. 7, Cross section through secondary phloem with xylem at far left. Phloem is poorly preserved, but tangential bands of axial parenchyma are intact; 1379 F bot, no. 3; X50. Fig. 8, Peripheral secondary phloem in cross section. Note groups of fibers surrounded by meristematic tissues; see also fig. 13; 831 Bj bot, no. 2; X40. Fig. 9, Longitudinal section through cambial zone, showing secondary tracheids with circular bordered pits (left) and secondary phloem (right); 831 B! side, no. 24; XIIO. Fig. 10, Possible formation of ray initials from fusiform initials (arrow). Repeating tangential bands of sieve cells, fibers, and parenchyma also evident; 861 D bot, no. 6; xllO. $A$ - axial parenchyma, $F=$ phloem fibers, $R=$ phloem rays, $S=$ sieve cells, $V=$ vascular cambium. 
TAB L E 2

DIAMETER OF AXIAL PARENCHYMA CELLS IN MEDULLOSA

\begin{tabular}{|c|c|c|}
\hline & $\begin{array}{c}\text { Radial } \\
\text { diameter (fim) }\end{array}$ & $\begin{array}{c}\text { Tangential } \\
\text { diameter (fxm) }\end{array}$ \\
\hline \multicolumn{3}{|l|}{ Next to cambium: } \\
\hline Mean $($ no. $=30) \ldots$ & 33.85 & 34.49 \\
\hline Range & 18.84-55.46 & 19.17-60.02 \\
\hline \multicolumn{3}{|c|}{ 10-12 rows from cambium: } \\
\hline Mean $($ no. $=30)$ & 56.23 & 36.28 \\
\hline Range & $27.74-87.48$ & $18.22-66.25$ \\
\hline \multicolumn{3}{|l|}{ Outer edge of phloem: } \\
\hline Mean $($ no. $=21)$ & 30.95 & 34.48 \\
\hline Range & $16.25-52.23$ & $19.79-47.80$ \\
\hline
\end{tabular}

Generally, the parenchyma bands are less distorted in the outer layers of the secondary phloem than the sieve elements (fig. 14). In the Steubenville stems, they are sometimes the only cells preserved (fig. 7). These cells are oblong, ca. 34 x 35 fim in diameter, and vary extensively in length, ranging from 96 to $385 \mathrm{~km}($ mean $=206 \mathrm{fim})$ (fig. 9). They are often present in vertical strands (figs. 9, 17).

A general increase in the diameter of the axial parenchyma cells is present from the cambium outward for ca. 10-12 cell layers (fig. 14). Beyond this point, the mean diameter of the axial parenchyma cells decreases as they are gradually crushed (fig. 4, table 2). The greatest change in diameter of these cells results from an increase in the radial dimension (table 2). Axial parenchyma cells are easily distinguished from the sieve elements in longitudinal section by their shorter length (ca. 10 times shorter than sieve elements) and by their nearly horizontal end walls (fig. 9). However, it is often difficult to differentiate these two cell types in cross section. Their range of diameters overlaps, although the size of the parenchyma cells partially depends on the number of cells in each tangential band, i.e., the number of anticlinal divisions in the initials, as well as on their position in relation to the cambium (table 2). In undistorted sections, axial parenchyma is located by its position just external to a band of phloem fibers (figs. 6, 10).

PHLOEM FIBERS. - At lower magnifications, the thickened walls of the phloem fibers are conspicuous in peel preparations and can be discerned, even in partially crushed sections, out to the periphery of the secondary tissue (figs. 4, 5, 8), since they are generally the last cells to be crushed in the older phloem tissue. The walls of most of the fibers are poorly preserved (figs. 6, 10), although the cells can still be identified by the distinctive, slitlike lumen (fig. 6, arrow). Each tangential band of fibers may be up to five cells wide radially and two to three cells tangentially, and is bordered on the inside by a band of sieve elements and on the outside by axial parenchyma cells (figs. 10, 15). Fibers are generally rectangular in cross section, measuring ca. $90 \mathrm{fxm}$ (tangential) x $35 \mathrm{|xm}$. The range of tangential diameters is large (71-151 $\mathrm{xm}$ ), depending on whether there are two, three, or four fibers in each band, and this depends, as in the axial parenchyma strands, on the number of anticlinal divisions in the initials or their immediate derivatives. Fibers are extremely long and pass from the plane of section in most specimens. The few cells that could be measured extend up to $4.2 \mathrm{~mm}$.

From the cambium outward, there is an increase in the radial diameter of the fibers (from 33 to 55 $(\mathrm{xm})$ and a slight increase in tangential diameter (from 22 to $28 \mathrm{im}$ ). These changes are accompanied by a large increase in the thickness of the cell wall (from 16 to $26 \mid \mathrm{xm}$ ). A group of fibers is present at the outermost edge of the secondary phloem in continuity with the radial rows of conducting elements (figs. 8, 21). The individual radial rows of fibers are often surrounded by a ring of meristematic cells (figs. 8, 13), and continued divisions can eventually isolate the fibers from the rest of the secondary phloem (fig. 13). The cells produced by this meristematic activity are histologically similar to those previously described in medullosan stems as an internal periderm (DELEVORYAS 1955).

PHLOEM RAYS. - Vascular rays are continuous from the secondary xylem into the secondary phloem and are regular in composition and size from species to species. The majority are five cells wide and range from three to nine cells wide. Each ray consists of three central rows of elongated cells (tangential diameter $45 \mathrm{~km}$ ) with a row of slightly larger cells (tangential diameter $67 \mathrm{lxm}$ ) forming a border on both sides (figs. 6, 11, 12). Many ray cells contain a dark brown material that may completely fill the lumen of the cell (figs. 10, 12, 14). Farther away from the cambium, the tangential width of the rays may increase by as much as $100 \mid \mathrm{xm}$ (figs. 11, 12). Although some cell divisions have been observed, this increase is, for the most part, a result of cell enlargement or stretching. Typical ray cells are ca. $88 \mathrm{|xm}$ in radial diameter $\mathrm{x} 46$ $\mid \mathrm{xm}$ close to the cambium and $85 \times 136 \mid \mathrm{xm}$ at the periphery of the phloem. While the tangential diameter increases considerably, the radial diameter decreases slightly. A few uniseriate rays extend up to 10 cells high, but most of the rays are multiseriate, usually from four to seven cells wide, and several hundred cells high (fig. 16).

SIEVE ELEMENTS-The sieve elements of the secondary phloem are bordered by a band of parenchyma cells internally and fibers externally (fig. 15). Each tangential band may contain from two to four sieve elements that are generally larger in diameter than the axial parenchyma (mean $=66$ $\mathrm{xm})$ with slightly thinner walls. Sieve elements are 

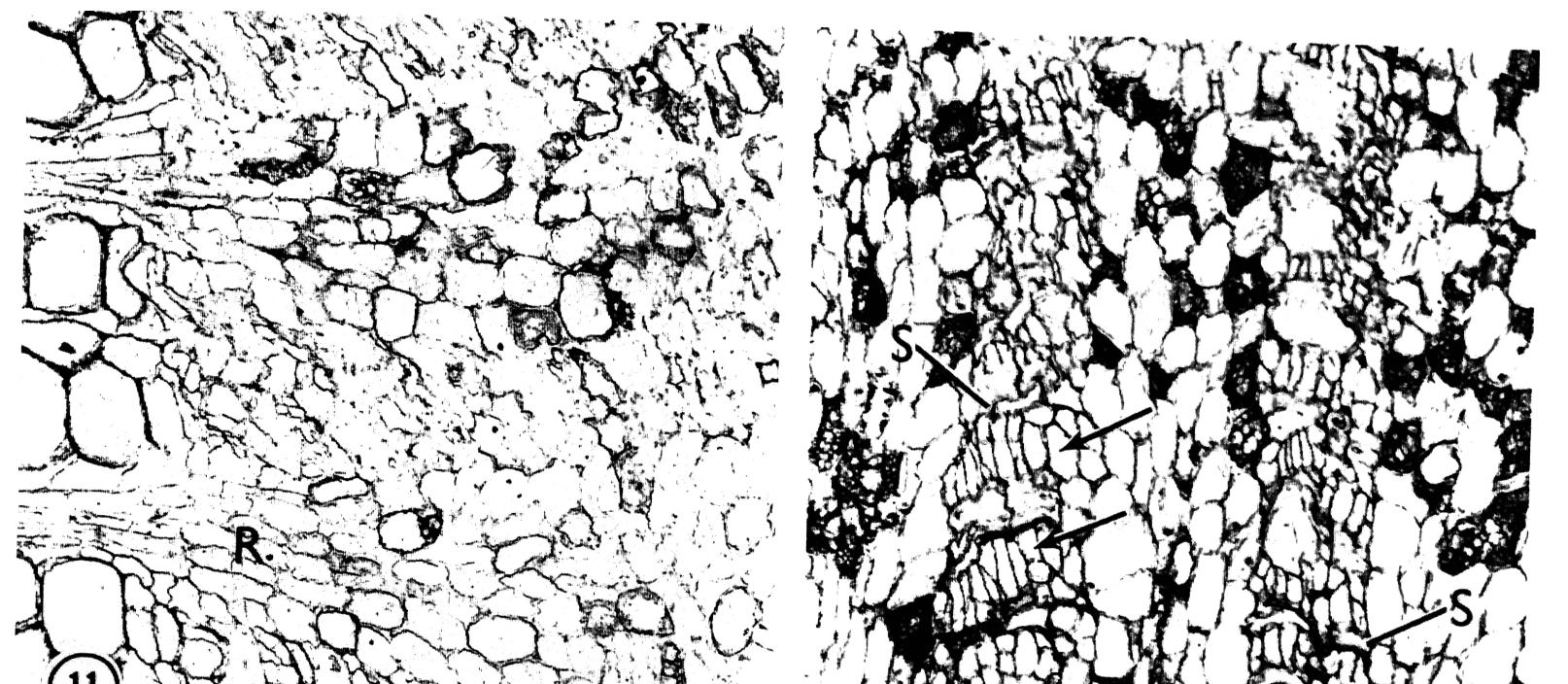

4 (11)

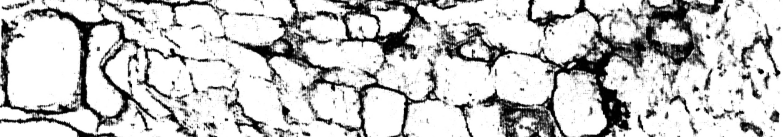

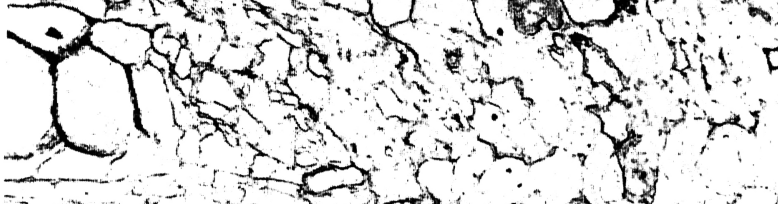

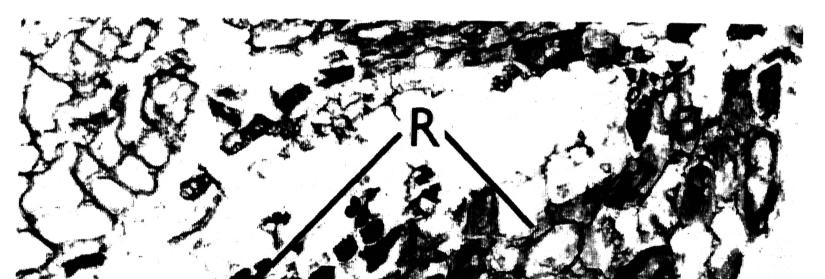

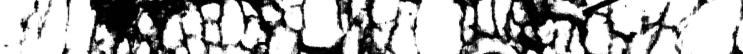

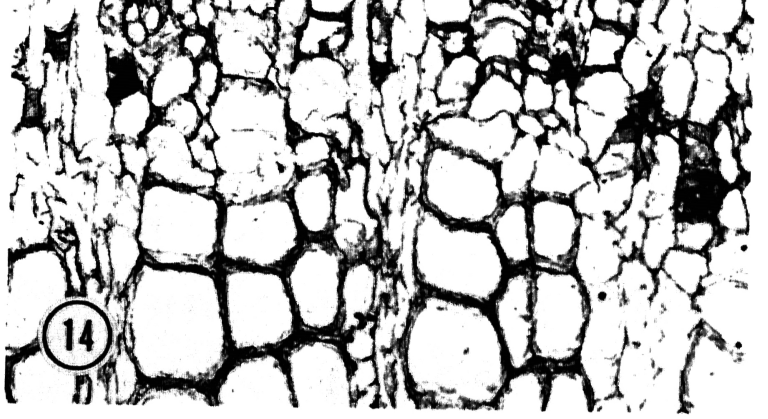

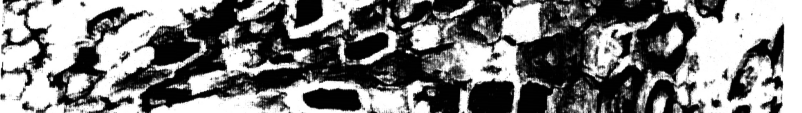
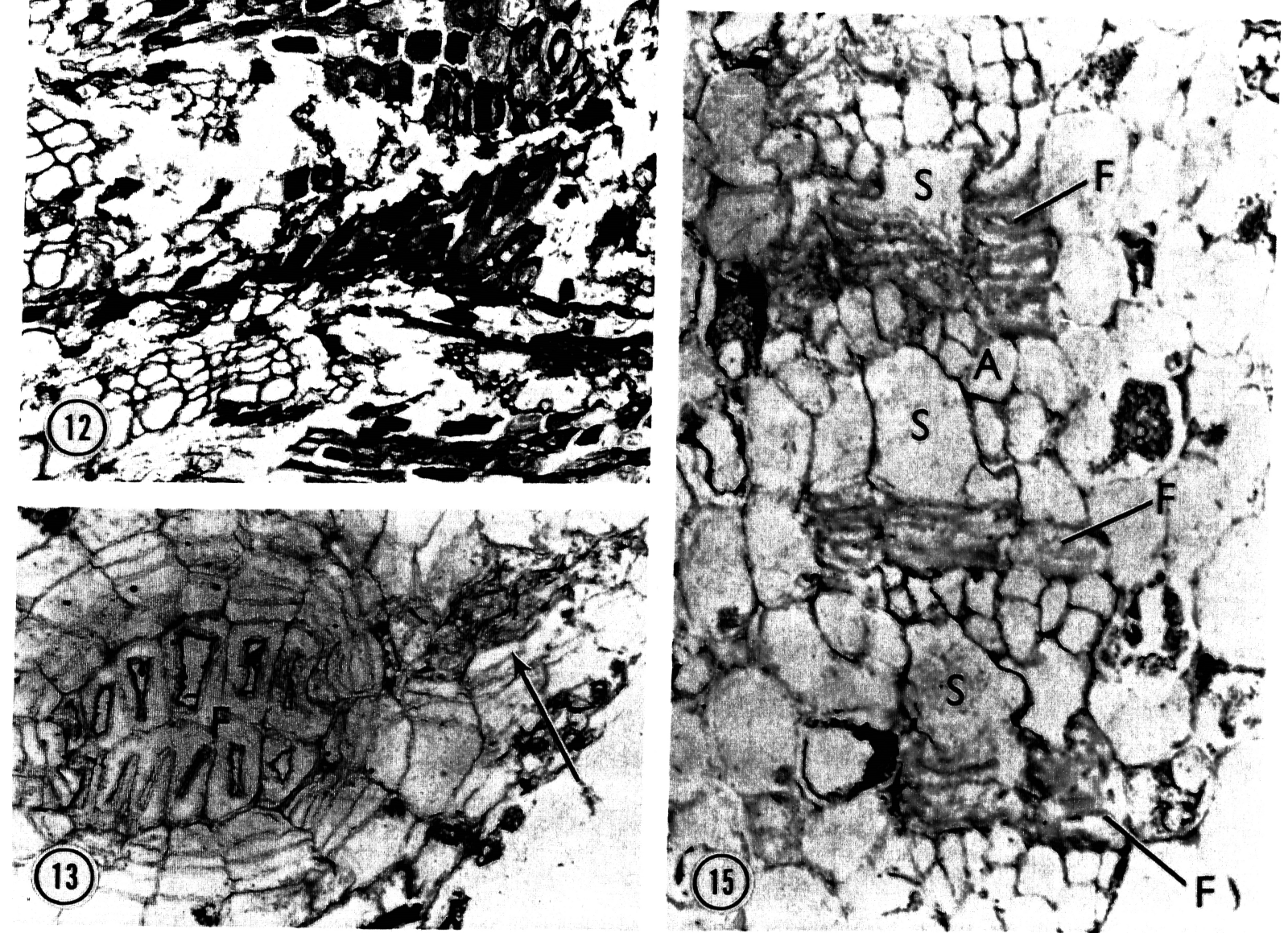

FIGS. 11-15.-Figs. 11, 13-15, Phloem of Medullosa noei; fig. 12, phloem of Medullosa sp. in cross section. Fig. 11, Poorly preserved specimen illustrating thin-walled ray cells and dilation of phloem rays; 861 D bot, no. 31; X65. Fig. 12, Specimen with dilated phloem rays. Note dark contents of ray cells and absence of other phloem cells; 1379 F bot, no. 3; X55. Fig. 13, Detail of group of fibers in peripheral secondary phloem illustrating thin-walled, meristematic cells ("internal periderm") surrounding fibers and possible primary phloem (arrow); 831 B, bot, no. 2; XIIO. Fig. 14, Transition zone showing inner and outer phloem, enlarged parenchyma cells (arrows), and collapsed sieve cells; 831 Bj bot, no. 18; X70. Fig. 15, Secondary phloem stained with malachite green to highlight bands of fibers. Also note relatively large, thin-walled sieve cells; 831 B! bot, no. 6; X176. $A=$ axial parenchyma, $F=$ phloem fibers, $R=$ phloem rays, $S=$ sieve cells. 

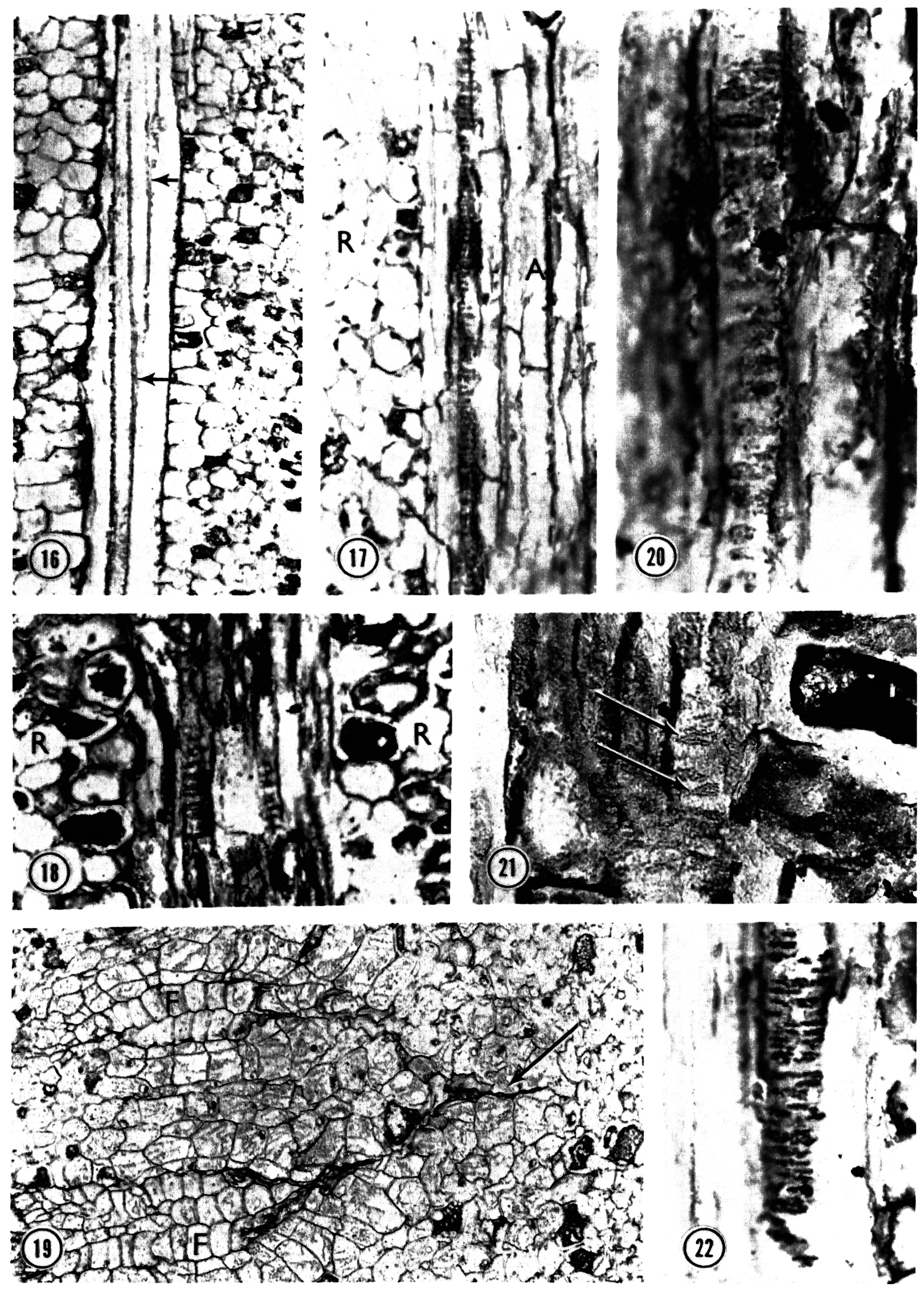

FIGS. 16-22.-Figs. 16, 17, 19, 20, 22, Phloem of Medullosa noei; figs. 18, 21, phloem of Medullosa sp. Fig. 16, Tangential section of phloem rays (left and right) and sieve cells (center) with tapered end walls. Arrows mark ends of sieve cells. Sieve areas are visible in side view as thin areas in the sieve-cell walls; $831 A_{i}$ side, no. 3; X50. Fig. 17, Longitudinal section of elongate sieve cell with numerous sieve areas and strands of axial parenchyma; $831 I^{\star}$ ! side, no. 1 ; $x$ 140. Fig. 18, Radial section showing two sieve cells and degraded aspect of sieve areas (center). Ray cells to right and left filled with dark contents; $1379 \mathrm{~F}$, a side, no. 26; X176. Fig. 19, Cross section through periphery of secondary phloem. Two groups of fibers visible at the left in continuity with crushed cells (dark line, arrow) representing possible primary phloem; 831 A, no. 4; x50. Fig. 20, Radial wall of sieve cell with relatively uncrowded, oval sieve areas; $831 \mathrm{Bj}$ side, no. 1; x350. Fig. 21, Sieve areas with sieve pores are visible as dark dots within the oval sieve areas (arrows); $1379 \mathrm{~F}$, a side, no. 16; X440. Fig. 22, Several sieve areas that are interpreted as being covered by callose deposits; $831 \mathrm{~A}$, side, no. $3 ; \mathrm{X} 240 . A=$ axial parenchyma, $F=$ phloem fibers, $R=$ phloem rays. 

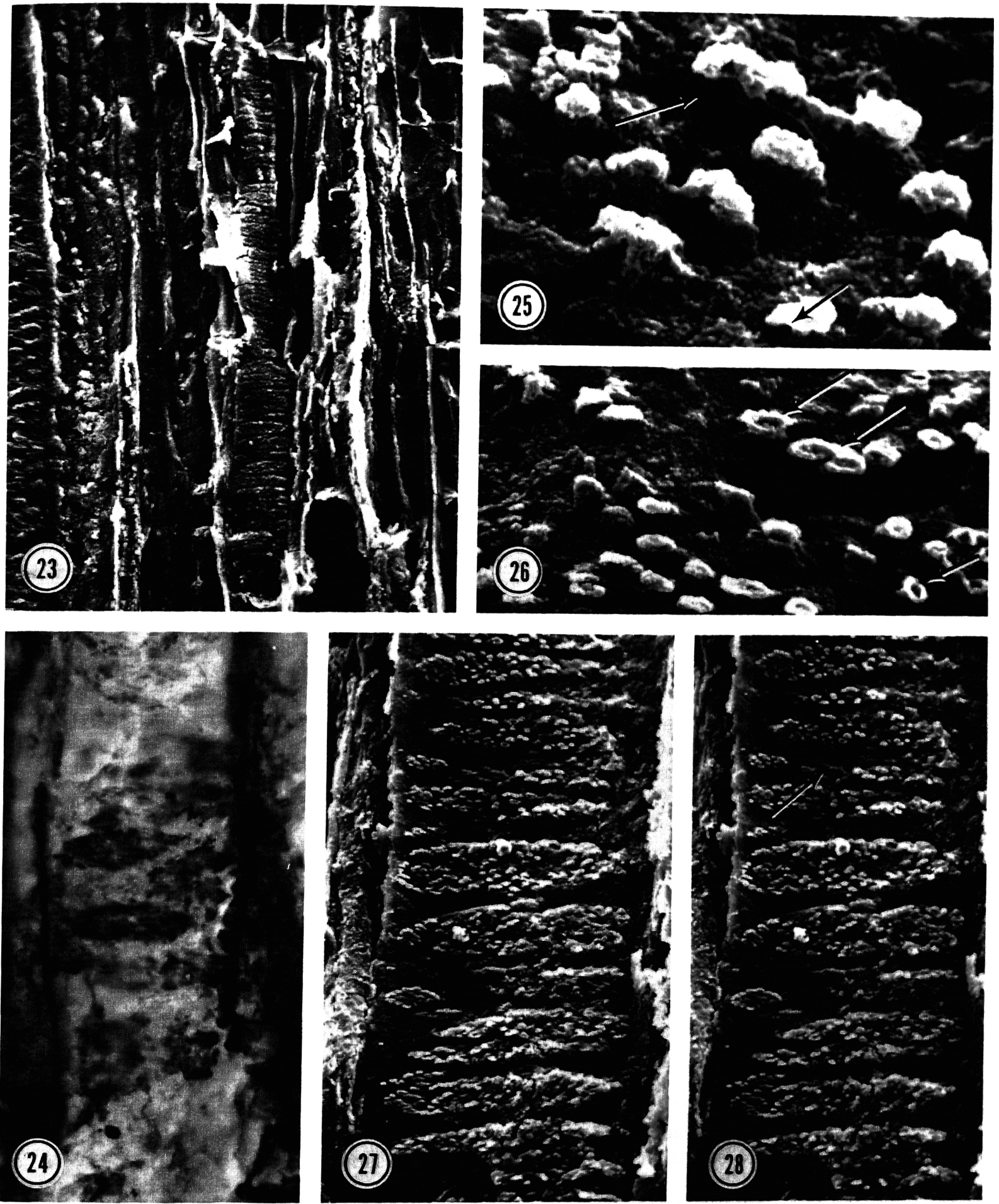

FIGS. 23-28.-Phloem of Medullosa noei. Fig. 23, Radial section through secondary xylem (left) and phloem. Sieve cell with numerous, oval sieve areas visible in center; 831 B,; X200. Fig. 24, Detail of sieve areas in upper part of fig. 18; 831 B, side, no. 1; X800. Fig. 25, Possible callose plugs within sieve area. Pores are visible beneath some of the plugs that have been displaced (arrows); $831 \mathrm{~B}^{\wedge} \times 10,000$. Fig. 26, Sieve area with several probable callose masses that appear as rings surrounding a central cavity (arrows); $831 \mathrm{~B}$, ; X5,000. Figs. 27, 28, Stereo pair of sieve cell showing elongate sieve areas on radial wall. Sieve pores generally covered by callose, but arrow indicates some open pores; $831 \mathbf{B}_{i} ; \mathbf{x 8 5 0}$. 
elongate, $1.6-4.2 \mathrm{~mm}($ mean $=3.1 \mathrm{~mm})$. End walls taper gradually and are difficult to distinguish from lateral walls. These oblique end walls are sometimes visible in cross sections as thin, diagonal lines across the lumen of the cells. Crowded, oval sieve areas occur on the radial and end walls of the sieve elements (figs. 18, 20, 24). The degree of specialization of the sieve areas is similar on both side and end walls, indicating that these cells are sieve cells. Sieve areas measure ca. $27.3 \times 7.8$ jim with numerous pores and are variably preserved. In stems from the Steubenville locality, e.g., sieve cells are partially degraded (fig. 19), and sieve areas appear as aggregations of dark brown spots on the cell walls (fig. 20). In specimens from other localities, sieve areas generally appear as dark ovals with darker spots (figs. 22, 24), although a few specimens exhibit groups of clear ovals on the sieve-cell walls (fig. 16). The dark spots are interpreted as the remains of callose plugs on the sieve pores, while the clearer sieve areas are assumed to lack callose, based on the position and shape of the dark-colored material.

Sieve areas were readily apparent on the sieveelement walls under the scanning electron microscope as elongate ovals slightly elevated above the remainder of the cell wall (figs. 23, 27, 28). Evenly distributed within the oval sieve areas are a number of "knob"-like structures that correspond in position to sieve pores. The "knobs" are interpreted as callose plugs adhering to the cell wall in the region of the individual sieve pores. Several plugs have a hollow center, thus forming a ring of callose that surrounds the inside of the pore and projects out slightly from the cell wall (fig. 26). In a few instances, the plug material was dislodged during maceration, and the sieve pore beneath is clearly visible (fig. 25, arrows). These pores are ca. 0.10.2 fim in diameter, and there are usually ca. 4050 pores per sieve area.

Changes IN THE OUter PHLOEM.-The secondary phloem of Medullosa shows several histological changes from the region of the most recently formed phloem cells next to the cambium out to the older elements at the periphery of the stele. In most specimens, the sieve elements, axial parenchyma cells, and phloem fibers appear to be fully differentiated immediately outside the narrow cambial zone (one to two cells from mature tracheids). These cells are assumed to be mature when they attain their full diameter.

One of the first histological changes associated with the transition from inner to outer phloem is an increase in the thickness of the cell walls in the phloem fibers that results in a $60 \%$ increase in the overall diameter of the cell (figs. 8, 13). As the walls become thicker, they also appear less dense, possibly indicating that the enlargement of the fiber walls results from passive hydration or swell- ing. At the same time, the cells within the bands of axial parenchyma increase ca. $60 \%$ in radial diameter (table 2, 10-12 rows from cambium). Although many sieve cells in extant plants deposit definitive callose on the sieve areas as they become nonfunctional, this phenomenon was not observed in Medullosa.

The sieve cells are generally the first cells to collapse in the outer phloem, and the tangential bands of parenchyma are visible some distance beyond the area in which sieve cells are first crushed (fig. 14). The early collapse of the sieve elements is no doubt related to their relatively thin walls, the expansion of the other cells in the secondary phloem, and the dilation of the phloem rays toward the periphery of the stele. Eventually, the axial parenchyma cells are also crushed, and the secondary phloem tissue is then delimited only by a row of fibers. Some specimens clearly show crushed wall material between the fiber cells, while this cannot be resolved in other instances. Finally, a discontinuous phellogen (= internal periderm of DELEVORYAS 1955) is often present in the vicinity of the outermost phloem fibers (figs. 8, 13, 21).

To the outside of the peripheral rows of fibers are a few cells that are extremely crushed and do not appear to be arranged in radial rows (figs. 13, 21). Some of these cells exhibit thickened walls and could represent the remains of primary phloem fibers or sieve cells. Although they are in the correct position for primary tissue, the cells are too poorly preserved for positive identification.

\section{Discussion}

Anatomically, Medullosa is one of the most complex plants known from Paleozoic strata. Since it was originally described from silicified specimens of Permian age, numerous species have been delimited (GOPPERT and STENZEL 1882; SCOTT 1899; DELEVORYAS 1955), ranging in age from the Upper Carboniferous (Westphalian A) to the Permian (PHILlips 1981). Only a few of these reports mentioned phloem tissue, and, in all cases, the tissue was fragmentary.

The earliest reports of Medullosa phloem were those of GOPPERT and STENZEL (1882), SOLMSLAUBACH (1897), and sCOTt (1899). The first two contributions were based on Permian fossils and the last on Upper Carboniferous material, but the phloem anatomy was remarkably similar. All described secondary phloem consisting of elongate thick-walled cells with narrow lumens and tapered end walls. The cells were arranged in radial rows and separated by parenchymatous rays. Since no thin-walled cells were present, SOLMS-LAUBACH (1897) concluded that these fiber-like cells must represent conducting elements. scot T (1899) agreed with this interpretation and suggested that these cells could not be fibers because: (1) the walls were light 
in color; (2) if the phloem of Medullosa was very fibrous, it would be preserved more often as a fossil; and (3) there were no other elements that could be sieve cells. Sсотт suggested that perhaps the cell walls were thin during the life of the plant but swelled prior to preservation.

BAXTER (1949) and STEWART (1951) described phloem in $\boldsymbol{M}$. endocentrica and M. pandurata, respectively, which consisted of groups of large, thinwalled cells, separated by ray parenchyma. BAXTER illustrated a transverse wall with very small pores preserved, and STEWART found more completely preserved sieve areas on the lateral walls of the sieve cells. Neither report described fiber cells in the secondary phloem. ARBER (1903) described secondary phloem in $\boldsymbol{M}$. anglica roots as radial groups of small "sieve tubes," accompanied by parenchyma cells and separated by vascular rays, and illustrated somewhat degraded sieve areas in both stems and roots. ROTHWELL and WHITESIDE (1974) also described well-preserved secondary phloem from medullosan roots. The sieve cells were elongate and in radial rows that were one to three cells wide. Thick-walled elements were seen in some older axes, but no sieve areas.

Phloem was also described in Sutcliffia, a stem genus that is structurally similar to Medullosa (PHILLIPS and ANDREWS 1963). SCOTT (1906) illustrated primary and secondary phloem in $\boldsymbol{S}$. insignis and distinguished sieve elements (elongate cells with tapered end walls) from phloem parenchyma (short cells with transverse walls) in longitudinal section. Scattered cells with dark contents were present in the primary phloem. DE FRAINE (1912) described a new species of the genus and found the phloem to be more like that described by SOLMS-LAUBACH (1897) and SCOTT (1899) in Medullosa. The elements were thick walled with a reduced lumen and appeared in longitudinal section as elongate cells with tapered ends.

On the basis of cellular composition, my material compares most closely with the nineteenthcentury descriptions of Medullosa (GOPPERT and STENZEL 1882; SOLMS-LAUBACH 1897; SCOTT 1899) and Sutcliffia phloem (DE FRAINE 1912). Although these studies found only fibers in the secondary phloem, the Medullosa stems under investigation here provide evidence that their specimens may not have reflected the true conducting state of the tissue. In the present stems, large groups of fibers occur only at the periphery of the secondary tissue, i.e., in the presumably nonfunctional phloem. There are several possible reasons why these fibers occur in this position with no intervening sieve cells or axial parenchyma. The vascular cambium may have initially produced a number of fibers, and thinwalled elements were not formed until later in development. Presumably, the primary phloem would function in conduction until secondary sieve cells matured. This sequence of events could account for the peripheral rows of fibers in my specimens and also explain the descriptions of GOPPERT and STENZEL (1882), SOLMS-LAUBACH (1897), and SCOTT (1899).

Another explanation for the distribution of fibers in Medullosa phloem assumes that the sieve cells and axial parenchyma were crushed as the phloem cells became nonfunctional, while the thick-walled fibers remained relatively unaffected by changes in the outer phloem. Alternatively, only the sieve cells may have been crushed, and some of the axial parenchyma cells underwent extensive wall thickening and differentiated into sclereids or fibers. The result in both cases would be a tissue composed almost exclusively of fibers and vascular rays. Crushing of sieve cells and sclereid formation from parenchyma cells are very common in the secondary phloem of many extant angiosperms and gymnosperms (HOLDHEIDE 1951; GRILLOS and SMITH 1959; ESAU 1969).

This sequence of events is a reasonable explanation for the distribution of fibers in Medullosa phloem and is supported by the occurrence in some specimens of proportionally more fibers in the older phloem (ROTHWELL and WHITESIDE 1974; the present specimens). Fibers also are more numerous in zones where the vascular cambium has undergone proliferation (see the location of fibers in $\boldsymbol{M}$. anglica phloem [SMOOT and TAYLOR 1981] and the present material). These zones are common in stems of Medullosa and closely resemble cambial and callus tissue formed in response to wounding or other trauma in living plants (BROWN and SAX 1962; ZIMMERMANN and BROWN 1980). The numerous fibers associated with these zones may simply reflect adjustments of the tissue, either by the production of extra fibers or by the obliteration of thin-walled cells during the wounding or recovery processes.

Another possibility that SCOTT (1899) and SOLMSLAUBACH (1897) discussed is that the so-called fibers in Medullosa stems are not truly fibers but are thin-walled elements whose walls have undergone some degradation and/or hydration following deposition. BARGHOORN $(\mathbf{1 9 4 9}, \mathbf{1 9 5 2})$ and BARGHOORN and SCOTT (1958) described the effects of degradation on tracheid walls in extant plants. They noted chemical and structural changes in the cell wall that are visible in fossil material and concluded that many plant remains must be fossilized prior to degradation since their cell walls remain relatively intact, especially in coal ball material. In my specimens, the tangential bands of fibers in the functional phloem are produced so regularly that it is very unlikely that they could have resulted from changes following deposition. On the basis of their histology and position, they appear to be a normal part of phloem development in this taxon. However, the cell walls of many of the peripheral fibers 
appear to have undergone some hydration or swelling, but whether this occurred prior to or following deposition is unclear.

The present material clearly illustrates that fibers were a normal part of the presumably functional phloem in Medullosa, but they were present as alternating, tangential bands of cells and not in large groups as in the nonfunctional tissues. The reports by BAXTER (1949) and STEWART (1951) of phloem in $M$. endocentrica and $M$. pandurata composed only of thin-walled elements are difficult to reconcile with my specimens, which have both thinand thick-walled elements. One possible explanation for this discrepancy is that the phloem tissue these authors examined was very close to the xylem and may have consisted of immature phloem elements or cambial zone initials. Although STEWART (1951) illustrated sieve areas in his paper, the phloem overall is fairly crushed and distorted. BAXTER'S (1949) material was reexamined, and it clearly shows that mature phloem with sieve areas was present. The differences in phloem structure could be taxonomic, but DELEVORYAS (1955) suggested that $\boldsymbol{M}$. endocentrica may represent a young stage in the development of M. noei. If so, then the production of fibers by the vascular cambium could be a phenomenon that develops later in the growth of the cambium. However, DELEVORYAS (1955) also placed M. pandurata (STEWART 1951) in $M$. noei but did not consider it to be a younger stage of stem growth. Much of the controversy over the presence or absence of fibers in Medullosa may be explained by the development of fibers from parenchyma cells in the older phloem, similar to the situation in Callistophyton (ROTHWELL 1975; SMOOT 1984). Thus, these cells would not be visible in developmentally younger material. The solution to this controversy must await a more detailed developmental study on phloem fibers in these other species of Medullosa.

The vegetative anatomy of the medullosan pteridosperms has been compared with that of extant members of the Cycadales many times (SCOTT 1899; WORSDELL 1906; DE FRAINE 1912; BANCROFT 1914; DELEVORYAS 1955; STEWART and DELEVORYAS 1956). SEWARD (1917), in particular, believed that the secondary xylem and phloem anatomy in these two groups was very similar, and DELEVORYAS (1955) noted that the stele in extant cycads could easily be derived from the typical stele of Permian medullosans by the loss of the "star rings." The phloem anatomy of Medullosa provides some support for the presumed relationship with extant cycads, especially at the level of tissue composition.

The discovery of fibers in the secondary phloem of Medullosa is the first clear evidence that this cell type was produced as a normal part of the functional phloem in the Paleozoic seed ferns. Fibers are not known to occur in any of the other
Carboniferous seed fern genera that have been examined (Callistophyton, RUSSIN [1981]; Lyginopteris, WILLIAMSON and SCOTT [1896]; Heterangium, HALL [1952]; Microspermopteris, TAYLOR and STOCKeY [1976]; and Calamopitys, GALTIER and H£BANT [1973]), and their presence in extant cycads has made comparison between these two groups difficult. The number of fiber cells in extant cycads may vary with development and position in the stem (MILLER 1919; CHRYSLER 1926), and this may also occur in Medullosa. CHRYSLER (1926) found that fibers in Microcycas were scarce in the earliest-formed phloem, becoming more abundant in later-formed layers. In Cycas media, MILLER (1919) noted that fibers were generally more common than sieve cells. Cycad fibers sometimes appear to be in tangential bands, but these are much more irregular than those in Medullosa (METTENIUS 1861; DIPPEL 1869; CHAMBERLAIN 1911; ESAU 1969 ).

Below the level of cellular composition, the information on cycad phloem is limited. Several studies have concentrated on types and contents of parenchyma cells (i.e., albuminous vs. crystalcontaining cells) (e.g., CHRYSLER 1926). Sieve cells have been described as elongate with gradually tapering end walls. Oval-elongate sieve areas with numerous pores occur on both radial and end walls (CHRYSLER 1926), and most sieve areas extend the full width of the radial walls (DIPPEL 1869; ESAU 1969).

Phloem histology of the Carboniferous medullosans can be compared with some Mesozoic cycadophytes, although there are few examples of phloem preservation, since the majority of the fossil members of this group are known from leaf compressions (MAMAY 1976). Perhaps the bestknown structurally preserved Mesozoic cycadophytes are the cycadeoids (WIELAND 1906, 1916; DELEVORYAS 1959, 1960, 1963, 1968; CREPET 1974). CHAMBERLAIN (1911) remarked that the phloem in Dioon appeared similar to that described by WIELAND (1906, pp. 76-77) in Cycadeoidea wielandii $\mathrm{W}$ ard. Both taxa contained a large number of phloem fibers and relatively few sieve elements in the secondary phloem, but the cells did not appear to be oriented in tangential bands. Details such as the length of sieve elements, location and size of sieve areas, etc., were not available.

One of the most complete descriptions of phloem in a Mesozoic cycadophyte was that of LIGNIER (1901) on Cycadeoidea micromyela Moriere. Near the cambium, the secondary phloem consisted of alternating bands of thin-walled, elongate cells (presumably sieve cells) and crushed cells identified as axial parenchyma. Farther away from the cambium, a few fibers were intercalated into the rows of parenchyma. As in extant cycads, the fibers became more numerous toward the periphery 
of the axis, and they seemed to replace sieve cells, which became rarer. The material was too poorly preserved for one to discern any details in longitudinal sections. ARCHANGELSKY and BRETT (1963) and GOULD (1971) noted the presence of phloem in the Triassic stems Michelilloa and Lyssoxylon, respectively, although in both cases the tissue was poorly preserved. GOULD discerned fibers in radial or tangential rows and a few thin-walled cells, while ARCHANGELSKY and BRETT identified fibers, sieve cells, and phloem parenchyma, separated by parenchymatous rays.

The phloem in the few Mesozoic cycadophytes that have been described is similar to that in both the medullosan pteridosperms and the extant cycads, at least as far as the composition of the tissue is concerned. The cell arrangement is more irregular in both the Mesozoic and extant representatives than in the Carboniferous taxa. Below this level, however, there is insufficient histological detail on the sieve cells of Mesozoic cycadophytes to make a comparison either with Paleozoic seed ferns or with extant cycads and other gymnosperms.

The discovery of fibers within the functional secondary phloem in Medullosa strengthens the proposed phylogenetic relationship with the $\mathrm{Cy}$ cadales. The occurrence of these cells in the medullosans and their absence in the other groups of Paleozoic pteridosperms are characters of taxonomic and phylogenetic importance.

\section{PHYLOGENETIC TRENDS IN GYMNOSPERM PHLOEM}

In comparison to our extensive knowledge on xylem in fossil plants and xylem evolution in general (CARLQUIST 1975), almost nothing is known about the phloem of fossil plants and comparatively little about its evolution (ESAU et al. 1953; CHEADLE and WHITFORD 1941; CHEADLE 1948; ZAHUR 1959). In her extensive reivew of phloem anatomy, development, and function, ESAU (1969, p. 359) stated that " . . paleobotany has provided no significant data that could be used in discussions of the evolutionary trends in the tissue." Many of the detailed contributions on fossil phloem have appeared since the publication of this work, but our knowledge of phloem phylogeny is still relatively meager compared with the data available on xylem evolution.

Most of the work on the phylogeny of phloem has been concerned primarily with angiosperms, and most often with monocotyledons. CHEADLE and WHITFORD (1941) examined sieve-tube members in a number of monocot taxa and proposed four evolutionary trends in sieve tubes: (1) localization of more specialized sieve areas on end walls, (2) change from oblique to more horizontal end walls, (3) change from compound to simple sieve plates on end walls, and (4) change from well-developed to poorly developed lateral sieve areas. CHEAdLE (1948) examined certain aspects of the structure of sieve-tube members quantitatively and discerned these correlations: (1) transverse or slightly oblique end walls were correlated with simple sieve plates, (2) more oblique end walls were correlated with compound sieve plates, and (3) very oblique end walls contained only compound sieve plates. CHEADLE (1948) also found that the least specialized sieve-tube members occurred in roots, and the most specialized in leaves and reproductive axes. Elements in the stem were generally intermediate between these two extremes. These contributions confirmed studies that proposed that the primitive sieve-tube member would be most similar to the sieve cell of conifers, i.e., elongate with very oblique end walls and similar sieve areas on both side and end walls (HEMENWAY 1911, 1913; MACDANIELS 1918).

It is immediately obvious that the four evolutionary trends of CHEADLE and WHITFORD (1941) parallel those described for xylem vessels (BAILEY 1953; CARLQUIST 1975). However, shortening of vessel elements is generally considered to be significant in the evolution of tracheary elements, and this trend has been difficult to quantify in secondary phloem because of further divisions of the phloem mother cells prior to maturation. ZAHUR (1959) tried to correlate septation of sieve-tube mother cells with the evolutionary advancement of particular taxa, but CARLQUIST (1975), on the basis of ecological constraints on xylem anatomy, felt that ZAHUR'S phylogenetic hypotheses were too simplified to be accurate.

Most of the contributions on phloem evolution have assumed that the gymnospermous sieve cell represents the primitive type from which sieve-tube members evolved, but little comparative work has been done on gymnosperms to confirm this hypothesis. DEN OUTER (1967) examined representatives of most of the families of living gymnosperms and placed them within a phylogenetic framework, based on cellular composition, arrangement of the cells within the tissue, and the type of intercellular connections present. He distinguished three types:

1. PSEUdotsuga TAXifolia TYPE.-This is considered the least specialized form, with a simple, homogeneous axial system consisting primarily of sieve cells with a few scattered parenchyma cells and fewer albuminous cells. This type is found in many members of the Pinaceae.

2. GINKGo BILOBA TYPE.-Axial system consists of alternating, tangential bands of phloem parenchyma and sieve cells; fibers occur scattered within the parenchyma bands. This type is found in the cycads, Araucariaceae, and some of the Podocarpaceae and Taxaceae. 
3. CHAMAECYPARIS PISIFERA TYPE.-Axial system of regularly repeating layers of phloem parenchyma, sieve cells, fibers, sieve cells, parenchyma, etc. Considered to be the most specialized type.

DEN OUTER (1967) noted that, according to this phylogenetic grouping, the most primitive type of axial system (Pseudotsuga) occurs with the most advanced type of ray system (heterogeneous rays with marginal ray tracheids). Similarly, the Chamaecyparis type contains relatively simple homogeneous rays. DEN OUTER defined evolutionary trends in gymnosperm phloem to consist of (1) an increase in the amount of axial parenchyma, (2) a decrease in the number of albuminous cells in the rays, (3) an increase in axial albuminous cells, (4) an increase in fibers, and (5) an increasingly regular arrangement of cell types in repeating, tangential bands. The basis for establishing the direction of these trends appears to be the belief of earlier workers that the conifers have generally undergone evolutionary reduction (DEN OUTER 1967). Our current knowledge of the phloem anatomy in fossil gymnosperms is too meager to enable us to offer a definitive statement on the direction of evolutionary trends. The fossil record, however, provides some idea of relative degrees of specialization in gymnosperm phloem.

At the level of cellular composition, secondary phloem anatomy in the seed ferns indicates that a complex arrangement of cell types was present in gymnosperm taxa as early as the Lower Carboniferous (Calamopitys, GALTIER and HEBANT [1 1973 ]). Although the majority of pteridosperms contain only sieve cells and parenchyma in their axial systems, the regularity of their arrangement in alternating bands provides indirect evidence on the specialization of the conducting cells. Parenchyma cells are associated with conducting elements in all vascular plants (see ESAU et al. 1953). This association can be relatively nonspecific, as in the vascular cryptogams, or very specialized, as in angiosperm sieve-tube members and companion cells. ESAU et al. (1953) suggested that the increasing cytoplasmic specialization of the sieve elements necessary for efficient conduction may be correlated with an increase in functional dependence between the sieve elements and neighboring parenchyma cells. This trend reaches its zenith in the angiosperms, but the association of gymnospermous sieve cells and albuminous cells can also be very specific.

A similar type of functional interdependence may have occurred in the Paleozoic pteridosperms, and this hypothesis could explain the regularity of the association between sieve cells and parenchyma bands in the secondary phloem of these plants. Certainly, this aspect of phloem anatomy in the seed ferns illustrates a stage of evolutionary develop- ment that is far beyond that seen in living or fossil vascular cryptogams. In addition, the existence of regularly repeating layers of cells and the presence of fibers in the phloem of Medullosa as early as the Carboniferous provide data that question the applicability of DEN OUTER'S (1967) evolutionary classification of gymnosperm phloem.

The morphology of the conducting elements of these Carboniferous seed plants is similar to that in extant gymnosperms. The sieve cells are elongate with very oblique end walls and numerous ovalcircular sieve areas on their radial and end walls. Since length of the elements is a variable character even in closely related taxa (ESAU 1969; CARLQUIST 1975), the histological characters available for phylogenetic consideration are the location, size, and shape of sieve areas, and the number and size of pores. Unfortunately, these characters have not been analyzed quantitatively in the extant gymnosperms, and the fossils generally appear to be similar to living examples. The discrete, well-defined sieve areas with regularly spaced pores and callose deposits in these Carboniferous specimens indicate that, as far as these anatomical features are concerned, the sieve cell in seed plants has changed little in the past 300 million years. In addition, the presence of callose cylinders within the sieve pores of presumably functional phloem elements indicates that these fossil sieve cells probably functioned similarly to their modern counterparts.

One of the most important aspects of these anatomically preserved Carboniferous fossils is that they provide for an examination of presumed phylogenetic trends in phloem. The trend suggested most often from comparative studies on extant plants involves the evolutionary development of angiospermous sieve-tube members from typical gymnospermous sieve cells. This change would include shortening of the cells, change in end wall configuration from very oblique to horizontal, and increased specialization of the sieve areas. Although my material does not provide evidence for the advanced stages in this evolutionary scheme (structure of sieve-tube members), the data show that the gymnospermous sieve cell was well developed by the Carboniferous. All of the Paleozoic seed ferns contain sieve cells that are closely comparable to those of living gymnosperms. They are very elongate and exhibit sieve areas that are specialized to the extent that they are confined to radial and end walls and are all similar in size and shape.

The present study illustrates that an examination of phloem anatomy in fossil plants can contribute considerably to our understanding of the evolutionary history of this tissue system. ESAU et al. (1953) suggested that the important factors in understanding trends of specialization in phloem tissue are, for the most part, cytophysiological and therefore unavailable in fossil material. They sug- 
gested that the cytological specialization of the sieve element has probably led to a functional interdependence between conducting cells and parenchyma cells. Comparisons between the phloem in vascular cryptogams and pteridosperms provide evidence for this same type of trend. In some of the less specialized Carboniferous ferns, phloem parenchyma is absent or only randomly arranged within the axis (SMOOT 1979), whereas in the pteridosperms, the parenchyma is so regularly arranged as to imply a close functional relationship between these cells and the sieve cells. In addition, progressive specialization of sieve areas and sieve pores can be observed in the fossil material. By analogy with extant phloem, the trend from scattered single pores and poorly organized sieve areas to regularly shaped sieve areas with evenly distributed pores and evidence of callose cylinders probably reflects a physiological specialization for more efficient translocation of solutes.

ESAU et al. ( 1953 ) cited the development of two types of phloem fibers within the secondary phloem of seed plants as possible indications of morphological specialization in secondary phloem. The first type differentiates close to the cambium as part of the functioning phloem, and the second differentiates later as fiber sclereids within the nonfunctioning phloem tissue. Similar cell types have been observed in the fossil material: both types in Medullosa and the second type only in Callistophyton (SмоOт 1984). The development of fiber sclereids in the presumably nonfunctional part of the phloem provides indirect evidence for a sequence of physiological and physical changes in the secondary phloem of seed ferns that parallels similar changes in extant taxa. ESA U et al. (1953) suggested that the type and arrangement of parenchyma cells in the phloem may also have phylogenetic significance. Although information on the distribution of phloem cells is available from fossil material, the classification of cell types is limited to those that can be inferred from their location, shape, etc. (companion cells in angiosperms and "erect" [ = some albuminous cells] in gymnosperms).

Finally, it is important to emphasize that the available information on fossil phloem, especially in plants from time periods outside the Carboniferous, is still quite limited. The phylogenetic trends suggested here will probably be modified as additional studies of phloem anatomy in fossil plants are completed.

\section{Acknowledgments}

I thank Dr. ROBERT W. BAXTER, Department of Botany, University of Kansas, Lawrence; Dr. GAR W. Rothwell, Botany Department, Ohio University, Athens; Dr. JefFry T. SChabiLion, Department of Botany, University of Iowa, Iowa City; and Dr. BENTON M. STIDD, Biology Department, Western Illinois University, Macomb, for the loan of specimens. Valuable advice from Dr. GARY L. FLOYD and discussions with Dr. MiChaEL A. Ci CHAN were very helpful. This work was completed while I was on a predoctoral fellowship from the American Association of University Women Educational Foundation and was supported in part by National Science Foundation grant DEB-79086076, a grant-in-aid of research from Sigma $\mathrm{Xi}$, the Scientific Research Society, and an Ohio State University Graduate School Alumni Research Award. Special thanks to Dr. тномаS N. TAYLOR, under whose guidance this work was done, for his support and advice.

\section{LITERATURE CITED}

ARBER, E. A. N. 1903. On the roots of Medullosa anglica. Ann. Bot. 17:425-433.

ARChANGELSKY, S., and D. W. BRETT. 1963. Studies on Triassic fossil plants from Argentina. II. Michelilloa waltonii nov. gen. et spec, from the Ischigualasto Formation. Ann. Bot. 27:147-154.

BAILEY, I. W. 1953. Evolution of the tracheary tissue of land plants. Amer. J. Bot. 4 0:4-8.

BANCROFT, N. 1914. Pteridosperm anatomy and its relation to that of the cycads. New Phytol. 13:41-68.

BARGHOORN, E. S. 1949. Degradation of plant remains in organic sediments. Bot. Mus. Leaflet, Harvard Univ. 14:120 .

1952. Degradation of plant tissues in organic sediments. J. Sedimentary Petrology 22:34-41.

BARGHOORN, E. S., and R. A. SCOTT. 1958. Degradation of the plant cell wall and its relation to certain tracheary features of the Lepidodendrales. Amer. J. Bot. 45:222-227.

BARTHOLOMEW, R. L., L. C. MATTEN, and E. F. WHEELER. 1970. Staining silicified woods. J. Paleontol. 44:905-907.

BASINGER, J. F., G. W. ROTHWELL, and W. N. STEWART. 1974. Cauline vasculature and leaf trace production in medullosan pteridosperms. Amer. J. Bot. 61:1002-1015.
BAXTER, R. W. 1949. Some pteridosperm stems and fructifications with particular reference to the Medullosae. Ann. Missouri Bot. Garden 36:287-353.

BEHNKE, H.-D. 1972. Sieve-tube plastids in relation to angiosperm systematics-an attempt towards a classification by ultrastructural analysis. Bot. Rev. 38:155-197.

. 1974. Sieve-element plastids of Gymnospermae: their ultrastructure in relation to systematics. Plant Syst. Evol. 123:1-12.

. 1981. Sieve-element characters. Nordic J. Bot. 1:381400.

BERTRAND, C.-E., and B. RENAULT. 1886. Recherches sur les Poroxylons-Gymnospermes fossiles des terrains houillers superieurs. Arch. Bot. Nord France 2:243-389.

BROWN, C. L., and K. SAX. 1962. The influence of pressure on the differentiation of secondary tissues. Amer. J. Bot. 49:683-691.

CARLQUIST, S. 1975. Ecological strategies of xylem evolution. University of California Press, Berkeley. 259 pp.

CHAMBERLAIN, C. J. 1911. The adult cycad trunk. BOT. GAZ. 52:81-104.

CHANG, Y.-P. 1954. Bark structure of North American conifers. U.S. Dep. Agr. Tech. Bull. 1095:1-86. 
CHEADLE, V. I. 1948. Observations on the phloem in the Monocotyledoneae. II. Additional data on the occurrence and phylogenetic specialization in structure of the sieve tubes in the metaphloem. Amer. J. Bot. 35:129-131.

CHEADLE, V. I., and N. B. WHITFORD. 1941. Observations on the phloem in the Monocotyledoneae. I. The occurrence and phylogenetic specialization in structure of the sieve tubes in the metaphloem. Amer. J. Bot. 28:623-627.

CHRYSLER, M. A. 1926. Vascular tissues of Microcycas calocoma. BOT. GAZ. 82:233-252.

COTTA, C. B. 1832. Pages 60-66 in Die Dendrolithen in Beziehung auf ihren inneren Bau. Arnoldische, Dresden and Leipzig. 89 pp.

CREPET, W. C. 1974. Investigations of North American cycadeoids: the reproductive biology of Cycadeoidea. Palaeontographica 148B:144-169.

DE FRAINE, E. 1912. On the structure and affinities of Sutcliffia, in the light of a newly discovered specimen. Ann. Bot. 26:1031-1066.

DELEVORYAS, T. 1955. The Medullosae-structure and relationships. Palaeontographica 97 B: 114-167.

- 1959. Investigations of North American cycadeoids: Monanthesia. Amer. J. Bot. 46:657-666.

- 1960. Investigations of North American cycadeoids: trunks from Wyoming. Amer. J. Bot. 47:778-786.

- 1963. Investigations of North American cycadeoids: cones of Cycadeoidea. Amer. J. Bot. 50:45-52.

- 1968. Investigations of North American cycadeoids: structure, ontogeny and phylogenetic considerations of cones of Cycadeoidea. Palaeontographica 121BM22-133.

DEN OUTER, R. W. 1967. Histological investigations of the secondary phloem in gymnosperms. Mededelingen Landbouwhogeschool Wageningen 67(7): 1-119.

DIPPEL, L. 1869. Pages 268-274 in Das Mikroskop und seine Anwendung. Zweiter Theil. Anwendung des Mikroskopes auf die Histiologie der Gewachse. Vieweg, Braunschweig.

ESAU, K. 1969. The phloem. Pages 322-338 in W. ZIMMERMANN, P. OZENDA, and $H$. D. WULFF, eds. Handbuch der Pflanzenanatomie. Vol. 5, pt. 2. Borntraeger, Berlin. 505 pp.

ESAU, K., V. I. CHEADLE, and E. M. GIFFORD. 1953. Comparative structure and possible trends of specialization of the phloem. Amer. J. Bot. 40:9-19.

GALTIER, J., and C. H£Bant. 1973. Sur le phloeme et le cambium d'une Calamopityac6e, ptfridospermale probable du Carbonifere inf\&ieur fran\$ais. Compt. Rend. Acad. Sci. Paris 276D:2257-2259.

G6PPERT, H. R., and G. STENZEL. 1882. Die Medulloseae. Eine neue Gruppe der fossilen Cycadeen. Palaeontographica 28:113-127.

GOULD, R. E. 1971. Lyssoxylon grigsbyi, a cycad trunk from the Upper Triassic of Arizona and New Mexico. Amer. J. Bot. 58:238-248.

GRILLOS, S. J., and F. H. SMITH. 1959. The secondary phloem of Douglas-fir. Forest Sci. 5:377-388.

HAU, J. W. 1952. The phloem of Heterangium americanum. Amer. Midland Natur. 47:763-768.

HEMENWAY, A. F. 1911. Studies on the phloem of the dicotyledons. I. Phloem of the Juglandaceae. BOT. GAZ. 51 : B I B S .

- 1913. Studies on the phloem of the dicotyledons. II. The evolution of the sieve-tube. BOT. GAZ. 55:236-243.

HOLDHEIDE, W. 1951. Anatomie mitteleuropaischer Geoholzrinden. Pages 193-367 in H. FREUND, ed. Handbuch der Mikroskopie in der Technik. Vol. 5. Umschau, Frankfurt.

JOY, K. W., A. J. WILLIS, and W. S. LACEY. 1956. A rapid cellulose peel technique in palaeobotany. Ann. Bot. 20:635637.

LIGNIER, O. 1901. Vegdtaux fossiles de Normandie. III. Etude anatomique du Cycadeoidea micromyela Mor. Mem Soc. Linn. Normandie 20:331-371.
MACDANIELS, L. H. 1918. The histology of the phloem in certain woody angiosperms. Amer. J. Bot. 5:347-378.

MAMAY, S. H. 1976. Paleozoic origin of the cycads. U.S. Geol. Surv. Prof. Paper 934:1-48.

METTENIUS, G. 1861. Beitrage zur Anatomie der Cycadeen. Abhandl. Math.-Phys. KI. Kongliche Sachsischen Ges. Wiss. 5:367-608.

MILlER, W. L. 1919. Polyxylic stem of Cycas media. BOT. GAZ. 68:208-221.

PHILLIPS, T. L. 1981. Stratigraphic occurrences and vegetational patterns of Pennsylvanian pteridosperms in Euramerican coal swamps. Rev. Palaeobotany and Palynology 32:526.

PHILLIPS, T. L., and H. N. ANDREWS. 1963. An occurrence of the medullosan seed-fern Sutcliffia in the American Carboniferous. Ann. Missouri Bot. Garden 50:31-51.

ROTHWELL, G. W. 1975. The Callistophytaceae (Pteridospermopsida). I. Vegetative structures. Palaeontographica 1518:171-196.

ROTHWELL, G. W., and K. L. WHITESIDE. 1974. Rooting structures of the Carboniferous medullosan pteridosperms. Can. J. Bot. 52:97-102.

RUSSIN, W. A. 1981. Secondary phloem of the Paleozoic pteridosperm Callistophvton boyssetii (Renault) Rothwell. BOT. GAZ. 142:165-175.'

SCOTT, D. H. 1899. On the structure and affinities of fossil plants from the Palaeozoic rocks. III. On Medullosa anglica, a new representative of the Cycadofilices. Phil. Trans. Roy. Soc. London 191 B:81-126.

- 1906. On Sutcliffia insignis, a new type of Medulloseae from the Lower Coal-Measures. Trans. Linn. Soc. London, 2d ser. (Bot.) 7:45-68.

SEWARD, A. C. 1917. Pages 87-90 in Fossil plants. Vol. 3. Pteridospermeae, Cycadofilices, Cordaitales, Cycadophyta. Cambridge University Press, Cambridge.

SMOOT, E. L. 1979. The phloem of Etapteris leclercqii and Botryopteris tridentata. Amer. J. Bot. 66:511-521.

- 1984. Secondary phloem anatomy in Callistophyton boyssetii (Renault) Rothwell and histological changes in the outer phloem. BOT. GAZ. 145:395-406.

SMOOT, E. L., and T. N. TAYLOR. 1981. The petrified pteridosperm stem Medullosa anglica from the Pennsylvanian of North America. Palaeontology 24:647-653.

SOLMS-LAUBACH, G. 1897. Ueber Medullosa Leuckarti. Bot. Zeit. 55:175-202.

STEWART, W. N. 1951. Medullosa pandurata sp. nov. from the McLeansboro Group of Illinois. Amer. J. Bot. 38:7 0 9-717.

STEWART, W. N., and T. DELEVORYAS. 1956. The medullosan pteridosperms. Bot. Rev. 22:45-80.

STEWART, W. N., and T. N. TAYLOR. 1965. The peel technique. Pages 224-232 in B. KUMMEL and D. RAUP, eds. Handbook of paleontological techniques. W. H. Freeman, San Francisco.

TAYlOR, T. N., and R. A. STOCKey. 1976. Studies of Paleozoic seed ferns: anatomy and morphology of Microspermopteris aphyllum. Amer. J. Bot. 63:1302-1310.

WIELAND, G. R. 1906. American fossil cycads. Carnegie Institute of Washington, Washington, D.C.

- 1916. American fossil cycads. Vol. 2. Taxonomy. Carnegie Institute of Washington, Washington, D.C.

williamson, W. C., and D. H. SCOTT. 1896. Further observations on the organization of the fossil plants of the CoalMeasures. HI. Lyginodendron and Heterangium. Phil. Trans. Roy. Soc. London 186 B:703-779.

WORSDELL, W. C. 1906. The structure and origin of the $\mathrm{Cy}-$ cadaceae. Ann. Bot. 20:129-159.

ZAHUR, M. S. 1959. Comparative study of secondary phloem of 423 species of woody dicotyledons belonging to 85 families. Cornell Univ. Agr. Exp. Sta. Mem. 358:1-160.

ZIMMERMANN, M. H., and C. L. BROWN. 1980. Trees: structure and function. Springer, New York. 